\title{
Fitness of early life stages in F1 interspecific hybrids between Dicentrarchus labrax and $D$. punctatus
}

\author{
Chin-Long KY ${ }^{1, a}$, Alain VERGNET ${ }^{2}$, Nicolas MOLINARI ${ }^{3}$, Christian FAUVEL $^{2}$ \\ and François BONHOMME ${ }^{4}$ \\ 1 IFREMER, Centre du Pacifique, Dép. Ressources biologiques et Environnement, UR Ressources marines \\ de Polynésie Française, BP 7004, 98719 Taravao, Tahiti, Polynésie Française \\ 2 UMR 5119 ECOSYM, UM2-UM1-CNRS-IRD-IFREMER, CC093, Université Montpellier 2, place Eugène Bataillon, \\ 34095 Montpellier Cedex 5, France \\ 3 UMR729 MISTEA, INRA, Montpellier SupAgro, Service DIM, CHRU de Montpellier, Université Montpellier 1, 2 place Viala, \\ 34060 Montpellier, France \\ ${ }^{4}$ Département Biologie intégrative, Institut des Sciences de l'Evolution, UMR 5554 Université de Montpellier 2, CC 63, \\ place Eugène Bataillon, 34095 Montpellier Cedex 5, France
}

Received 1st July 2011; Accepted 26 March 2012

\begin{abstract}
Inter- and intraspecific crossbreeding experiments were conducted to evaluate the aquaculture potential of hybrids in the genus Dicentrarchus, focusing on fertilisation and hatching success. The experimental design consisted of 24 controlled crosses in which individual and pooled fertilisations were made between wild $D$. labrax individuals ( 8 dams and 5 sires originating from West Mediterranean and Atlantic populations) and wild $D$. punctatus (6 sires). Three experiments were successively performed: (1) dams from the Mediterranean population, individually considered to have good egg quality, (2) dams from Mediterranean population, individually considered to have poor egg quality and (3) crossbreeding using pooled eggs from the Atlantic population. In each case, batches of these eggs were fertilized by sperm from males of the two species. Sperm cell quality (concentration and motility) was verified before experimentation in all cases and equal numbers of sperm cells from each male were used to individually (without inter-sire competition) fertilise egg batches. Through the repeated artificial crosses between female common sea bass Dicentrarchus labrax (Linnaeus 1758) and male spotted sea bass D. punctatus (Block 1792), these experiments showed that no post-zygotic reproductive barriers exist to interspecific hybridisation between these two species when using D. labrax as dams and D. punctatus as sires. Phenotypically, the F1 hybrids were easily recognisable: they inherited the characteristic black spots of D. punctatus. Furthermore, embryo survival was significantly higher in interspecific crosses compared with intraspecific controls, showing increased fitness for this trait (increased performance at early life stage). Then, the experimental breeding design validates the observation that West Mediterranean and Atlantic common sea bass populations are different. Indeed, the inter-population crosses (between West Mediterranean dams and Atlantic sires) also revealed increased fitness at early life stages in comparison with the progeny of intra-Atlantic population crosses. However, these individuals were still smaller than their interspecific counterparts. The ability to produce viable F1 hybrids will have significant implications for the practical improvement of sea bass aquaculture.
\end{abstract}

Key words: Sea bass / Hybrid progeny / Offspring quality / Fitness / Dicentrarchus labrax / Dicentrarchus punctatus

\section{Introduction}

Interspecific hybridisation is an complementary approach that can used in breeding programs to improve desirable traits (such as growth rate, flesh quality, disease resistance and environmental tolerance) of cultured stocks via the exploitation of potential positive heterosis (hybrid vigour) in F1 crossbred offspring (Bartley et al. 2001). Indeed, in most cases heterosis in some reproductive fitness traits is expected when the parental lines are genetically distinct (Fairfull et al. 1987; Flock et al. 1991). Evidence of superior performance and interspecific hybrid vigour has been reported in a wide variety of fish species

\footnotetext{
a Corresponding author: chinky@ifremer.fr
} 
(Hulata 1995; Bartley et al. 2001). The success of interspecific hybridisation supposes that two levels of barrier to reproduction are overcome: (1) prezygotic barriers, which block various stages of reproduction from mating through fusion of the two pronuclei, and (2) postzygotic barriers, which are commonly stronger in fish than prezygotic ones and can induce the abortion of embryos (Campbell 1990). These reproductive barriers can be easily evaluated by assessing the development of fertilised eggs in interspecific crosses.

Three examples illustrate the interest of using hybrids of aquaculture fish. The striped bass (Morone saxatilis), the sister genus of Dicentrarchus, when exposed to a standardised confinement stress, had lower survival and resistance to infection than hybrid bass (M. saxatilis $\times$ M. chrysops and M. saxatilis $\times$ M. americana) (Noga et al. 1994). A significant proportion of farmed sturgeon is composed of interspecific hybrids (Acipenser naccarii $\times$ A. transmontanus) due to their high productive performance for caviar and flesh (Congiu et al. 2001). Finally, another well-known example of the semi-intensive culture of hybrid fish is the red Nile tilapia, which is a hybrid of Oreochromis niloticus and O. mossambicus (Medeiros et al. 2007).

Obtaining high quality gametes is one of the most important limiting factors in the modern aquaculture industry, for both freshwater and seawater species (Bromage 1995; Kjorsvik et al. 1990; Brooks et al. 1997; Bobe and Labbé 2010), as fertilisation rate $(\%)$ and hatching rate (\%) are important production criteria. Egg quality can be defined as the potential of an egg to hatch into a viable larva. In some species, morphological aspects of larvae are used as indicators of gamete quality (Kjorsvik 1994; Kjorsvik et al. 2003). Egg quality is determined by several parameters that frequently change before and during the reproductive season. These include several extrinsic factors that can modify the female endocrine status during oogenesis, such as physicochemical parameters of water, photoperiod (Bromage et al. 1992, 1994), the amount and quality of ingested food (Watanabe and Kiron 1995), broodstock stress and the over-ripening of eggs after ovulation (Campbell et al. 1992, Christiansen and Torrisen 1997, Fauvel et al. 1992). The intrinsic properties of the egg, such as its genes, the nutrients in the yolk sac, and the contribution of the parental transcripts and proteins after fertilisation, can also determine the egg quality (Brooks et al. 1997; Aegerter et al. 2005; Bonnet et al. 2007a, 2007b; Crespel et al. 2008; Desvignes et al. 2011). In addition, the incubation environment also affects the success of production of viable offspring, both in the wild and in captivity (Lam 1994; Nagahama 1995).

The European (or common) sea bass, Dicentrarchus labrax (Linnaeus 1758) is efficiently bred in captivity and reared intensively in Mediterranean mariculture. Sea bass could be considered as a cultured species model, because its biology, physiology, behaviour, reproduction and phenotypic diversity have all been extensively studied. Previous genetic studies based on allozymes (Allegrucci et al. 1999), mitochondrial and random amplified polymorphic DNA (RAPD) markers
(Caccone et al. 1997) have led to the identification of three genetically distinct populations: north-eastern Atlantic, western Mediterranean and eastern Mediterranean (Lemaire et al. 2005).

Sea bass shows a seasonal reproductive cycle with eggs produced when the environmental conditions are most conducive to survival. According to Mayer et al. (1990), wild sea bass females spawn discrete clutches of eggs at short intervals of time during the reproductive season (in winter). In captivity, they spawn spontaneously only 2 or 3 times over the reproductive season, i.e., once a month (C. Fauvel, pers. comm.). Short interval spawning by stimulation using slow release implants of an artificial hormone was tested by Fornies et al. (2001), but led to very low quality spawns; probably due to over-stimulation of under-ripe eggs. The species can be classified as a "group synchronous" spawner with long final maturation cycles (Wallace and Selman 1981).

Little is known about the spotted sea bass, Dicentrarchus punctatus (Bloch 1792), which is not reared at commercial scale due to its slow growth performance compared with the wellknown D. labrax (Allegrucci et al. 1997). Although no spontaneous mating has been observed between these two species, this is probably due to differences between their sexual maturity times and behaviour in the wild (Bonhomme et al. 2002). The diploid chromosome number of both species is $2 n=48$ (Viturri et al. 1990), and studies at cytogenetic and molecular levels using three multi-gene families confirm that they are closely related (Merlo et al. 2010).

In the present study, we report the estimation of reproductive and early life characteristics, i.e., fertilisation and hatching rate, in interspecific hybrids between D. labrax, used as dams and D. punctatus, used as sires, in comparison with intraspecific crosses of D. labrax. Interspecific crosses were carried out by replicated artificial insemination. The feasibility of producing hybrids from these two species for practical use in sea bass aquaculture and their potential for future sea bass genetic improvement programs are discussed.

\section{Materials and methods}

\subsection{Broodstock}

D. labrax and D. punctatus were collected in the wild by fishermen specialising in live fish capture for genitor introduction to aquaculture farms and the public aquarium trade (http:// www.poissons-vivants.com/index.htm). Fish were caught during spring and summer in 2002 to 2005 using nets and transported directly upon capture to the Ifremer aquaculture station at Palavas-les-flots (South of France). They were then maintained as broodstock for at least for 2 years in recirculating water systems in $15 \mathrm{~m}^{3}$ tanks under natural conditions of photoperiod and temperature, which ranged from $10^{\circ} \mathrm{C}$ in winter to $25^{\circ} \mathrm{C}$ in summer. The fish were hand-fed: (1) daily with commercial pellets for marine fish (Le Gouessant) to apparent satiety and (2) once a week with frozen sardines. All fish were individually marked 
Table 1. Broodstock used for interspecific hybridisation between D. labrax and D. punctatus: Eight dams from the West Mediterranean sea (WM) or Atlantic Ocean (AT), and eleven sires from the Atlantic were used. The genotype nomenclature is as follows: (1) West Mediterranean, D. labrax dams: $\mathrm{F}_{\mathrm{WM}}$, (2) Atlantic, D. labrax dams and sires: $\mathrm{F}_{\mathrm{AT}}$ and $\mathrm{M}_{\mathrm{AT}}$, respectively, (3) D. punctatus, males: $\mathrm{P}$. The last column indicates which experiments the genitors were used for.

\begin{tabular}{|c|c|c|c|c|}
\hline Species & Sex & $\begin{array}{l}\text { Geographic } \\
\text { origin }\end{array}$ & Genotype & $\begin{array}{c}\text { Experimental } \\
\text { design }\end{array}$ \\
\hline \multirow[t]{13}{*}{ D. labrax } & Female & WM & $\mathrm{F}_{\mathrm{WM}-1}$ & 1 \\
\hline & Female & WM & $\mathrm{F}_{\mathrm{WM}-2}$ & 1 \\
\hline & Female & WM & $\mathrm{F}_{\mathrm{WM}-3}$ & 1 \\
\hline & Female & WM & $\mathrm{F}_{\mathrm{WM}-4}$ & 2 \\
\hline & Female & WM & $\mathrm{F}_{\mathrm{WM}-5}$ & 2 \\
\hline & Female & $\mathrm{AT}$ & $\mathrm{F}_{\mathrm{AT}-1}$ & 3 \\
\hline & Female & AT & $\mathrm{F}_{\mathrm{AT}-2}$ & 3 \\
\hline & Female & AT & $\mathrm{F}_{\mathrm{AT}-3}$ & 3 \\
\hline & Male & AT & $\mathrm{M}_{\mathrm{AT}-1}$ & 1 \\
\hline & Male & AT & $\mathrm{M}_{\mathrm{AT}-2}$ & 2 \\
\hline & Male & $\mathrm{AT}$ & $\mathrm{M}_{\mathrm{AT}-3}$ & $2 \& 3$ \\
\hline & Male & AT & $\mathrm{M}_{\mathrm{AT}-4}$ & 3 \\
\hline & Male & AT & $\mathrm{M}_{\mathrm{AT}-5}$ & 3 \\
\hline \multirow[t]{6}{*}{ D. punctatus } & Male & AT & $\mathrm{P}_{1}$ & 1 \\
\hline & Male & $\mathrm{AT}$ & $\mathrm{P}_{2}$ & 1 \\
\hline & Male & AT & $\mathrm{P}_{3}$ & $2 \& 3$ \\
\hline & Male & AT & $\mathrm{P}_{4}$ & $2 \& 3$ \\
\hline & Male & AT & $\mathrm{P}_{5}$ & 3 \\
\hline & Male & AT & $\mathrm{P}_{6}$ & 3 \\
\hline
\end{tabular}

using passively integrated transponder (PIT) tags. In these conditions the spawning season occurred from mid-January until the end of March, and spermiation season broadly covered the period.

Eight dams (all D. labrax) and 11 sires (6 D. punctatus and 5 D. labrax) were used for this study. D. labrax dams from the West Mediterranean populations will be referred to as $\mathrm{F}_{\mathrm{WM}}$; D. labrax dams and sires from the Atlantic population as $\mathrm{F}_{\mathrm{AT}}$ and $\mathrm{M}_{\mathrm{AT}}$, respectively; and D. punctatus sires as $\mathrm{P}$ (Table 1). The selection criteria for fish used in the present experiment were that they should be healthy, with an adequate maturation stage (postvitellogenic stage $\mathrm{C}$, as proposed by Fauvel and Suquet 1999). Females and males weighed $2 \mathrm{~kg}( \pm 200 \mathrm{~g})$ and $1 \mathrm{~kg}( \pm 200 \mathrm{~g})$, respectively.

\subsection{Female induction and precocious egg quality assessment}

In order to choose the best females to use in crosses, ovarian biopsies were made. These were started shortly after the beginning of the reproductive season (indicated by the first spontaneous spawns) and were performed fortnightly on each female under anaesthesia, using a flexible plastic catheter designed for human endometrium sampling ("Pipelle de Cornier", laboratoire CCD, Paris, France). Egg maturation stage was assessed based on vitellus appearance and nucleus migration, according to Fauvel et al. (1999) and Fauvel and Suquet (1999).

Females with ovaries at stage $\mathrm{C}$ (initiation of lipid droplet formation and nucleus migration), were stimulated by a single injection of luteinising hormone releasing hormone analog (LHRHa) (Sigma) at $10 \mu \mathrm{g} \mathrm{kg}^{-1}$ body weight. In order to prevent spontaneous egg release, they were then transferred individually into $1 \mathrm{~m}^{3}$ tanks at $11-13{ }^{\circ} \mathrm{C}$ with a recirculating water system. Ovulation occurred about $72 \mathrm{~h}$ after hormonal injection. The eggs were collected by stripping females and were assessed before fertilisation for their intrinsic quality according to four morphological features: perfect roundness, development of a perivitelline space, vitellus translucency and low number of lipid droplets. Only good and homogeneous egg batches were used for the experiment, except for $\mathrm{F}_{\mathrm{WM}-4}$ and $\mathrm{F}_{\mathrm{WM}-5}$ which produced poor quality eggs.

\subsection{Collection and assessment of sperm quality}

A random catch of sires was realised in the D. labrax or D. punctatus broodstocks. From these samples, sperm was obtained by applying slight pressure on the abdomen of a running male with milt. The external urogenital pore area was wiped dry with paper towel before collecting sperm. Urine and potentially urine-polluted semen were carefully discarded (identified by differences in colour and viscosity). To avoid sea water and faeces contamination, the initial male ejaculate was discarded. Sperm was drawn from males into a $2 \mathrm{ml}$ syringe without a needle and kept refrigerated at $4{ }^{\circ} \mathrm{C}$ until needed.

Sperm cell quality was checked for concentration and motility in both species, according to the procedure of Fauvel et al. (1999):

- Concentration: Milt was first diluted in a 10-ml test tube by adding $10 \mu \mathrm{l}$ milt to $9990 \mu \mathrm{l}$ distilled well water (dilution 1:1000) and then mixed using a vortex mixer. The sperm concentration was determined using a spectrophotometer at $260 \mathrm{~nm}$ wavelength to assess optical density, as a linear regression exists between this method and conventional sperm cell number assessment by haemocytometer counting (Fauvel et al. 1999).

- Motility: Sperm motility was checked at $40 \times$ magnification under a light microscope connected to a camera and video monitor. First, $10 \mu \mathrm{l}$ sperm were diluted in $250 \mu \mathrm{l}$ non activating medium, NAM (Fauvel et al. 1998). Then, $10 \mu$ diluted sperm were activated by the addition of $1 \mathrm{ml}$ seawater to give a final dilution of $1 / 2500$. Just at the point of activation, sperm were introduced into a Thoma counting cell already focused under the video-microscope (Axiolab Zeiss). This process took less than $10 \mathrm{~s}$, enabling motility to be estimated visually by two observers, 
according to Suquet et al. (1992). All the sire samples showing high initial motility ( 80 to $100 \%$ motile spermatozoa, spz) were choosen for experimentation.

After assessment of the concentrations of the different semens, they were individually adjusted to $10^{10} \mathrm{spz}$ per ml by dilution in a non activating medium (Fauvel et al. 1998). Then the fertilization were performed using a similar volume of diluted sperm containing $200000 \mathrm{spz}$ per egg according to Fauvel et al. (1999).

\subsection{Experimental mating design}

Eggs were divided into equally-sized volumes of $50 \mathrm{ml}$, which were put in individual $200 \mathrm{ml}$ beakers and fertilised with a mixture of $50 \mu \mathrm{l} \mathrm{sperm}$ and $25 \mathrm{ml}$ seawater. Just after fertilization, the eggs were transferred into small cylindro-conical incubator-tanks (volume $=50 \mathrm{~L}$ ) with recirculating sand-filtered water (at $13{ }^{\circ} \mathrm{C}$ and $38 \mathrm{~g} \mathrm{~L}^{-1}$ salinity) that was disinfected with UV light. Aeration from the bottom of the incubators provided gentle agitation of the eggs and surface seawater.

Three experiments were successively performed during the natural reproductive season, with experiments two weeks apart. All three experiments used a complete factorial design, i.e. all possible combinations of dam $\times$ sire (Lynch and Walsh 1998).

- Experiment 1: Dams with good egg quality.

The factorial breeding scheme $(3 \times 3)$ used three dams, $\mathrm{F}_{\mathrm{WM}-1}, \mathrm{~F}_{\mathrm{WM}-2}$, and $\mathrm{F}_{\mathrm{WM}-3}$, crossed with three sires: two D. punctatus, $\mathrm{P}_{1}$ and $\mathrm{P}_{2}$, and one D. labrax, $\mathrm{M}_{\mathrm{AT}-1}$.

- Experiment 2: Dams with poor egg quality.

The factorial breeding scheme $(2 \times 4)$ used two dams, $\mathrm{F}_{\mathrm{WM}-4}$ and $\mathrm{F}_{\mathrm{WM}-5}$, individually crossed with four sires: two D. punctatus $\mathrm{P}_{3}$ and $\mathrm{P}_{4}$, and two D. labrax sires $\mathrm{M}_{\mathrm{AT}-2}$ and $\mathrm{M}_{\mathrm{AT}-3}$.

- Experiment 3: Crossbreeding using pooled eggs from the D. labrax Atlantic population.

Crosses used the pooled eggs from the 3 dams, $\mathrm{F}_{\mathrm{AT}-1}, \mathrm{~F}_{\mathrm{AT}-2}$, and $\mathrm{F}_{\mathrm{AT}-3}$. Each dam was individually stripped and eggs were then equally mixed ( $300 \mathrm{ml}$ of eggs per dam to obtain a total volume of $900 \mathrm{ml}$ ). The sperm of seven sires was individually collected: four D. punctatus $\left(\mathrm{P}_{3}, \mathrm{P}_{4}, \mathrm{P}_{5}\right.$ and $\left.\mathrm{P}_{6}\right)$ and three $\mathrm{D}$. labrax $\left(\mathrm{M}_{\mathrm{AT}-3}\right.$; $\mathrm{M}_{\mathrm{AT}-4}$ and $\left.\mathrm{M}_{\mathrm{AT}-5}\right)$.

\subsection{Offspring quality parameters}

Fertilisation rate $(\%)$ of the different crosses was individually evaluated $3 \mathrm{~h}$ post-fertilisation. Around 500 eggs were sampled from each incubator-tank/family under strong seawater agitation and placed in $200 \mathrm{ml}$ containers. These eggs were then transferred to a Dolfuss counting cell in which eggs are randomly distributed between the small squares. The ratio between fertilised and non fertilised eggs was established by two different observers based on the first 100 eggs observed, starting from a randomly chosen square. For each incubator, four samples of 500 eggs were evaluated ( 2 trials per counter). Fertilised eggs were characterised by visibly dividing cells ( $2-4$ cells stages, $3 \mathrm{~h}$ post fertilisation).
On the day of fertilisation, another 500 eggs were sampled from each incubator-tank and placed in a 200-ml Erlenmeyer. Offspring hatched approximately 5 days post-fertilisation under water conditions of $13{ }^{\circ} \mathrm{C}$ temperature and $20 \mathrm{~g} \mathrm{~L}^{-1}$ salinity. The hatched larvae and remaining eggs were then transferred to a Petri dish for counting. The first 100 larvae/eggs (hatching rate in \%) were counted under a dissecting microscope (Stemi 2 000$\mathrm{C}$, Zeiss) by two different counters, beginning at a random starting point. For each incubator, three trials $(n=3)$ of 500 larvae/ eggs were performed in duplicate ( 2 trials per counter).

\subsection{Statistical analysis}

The normality of the distributions were assessed using the Shapiro-Wilk test. Due to non normality of the distributions, median of the distributions are presented and non parametric Kruskal-Wallis tests were used to test for differences among the groups. This was followed by multiple comparison procedures to determine differences between groups, performed using Mann-Whitney tests. Corrections for multiplicity test were not used. A $p$-value of less than 0.05 was considered significant. Statistical analysis was performed using $\mathrm{R}$ software package (version 2.13.0).

\section{Results}

\subsection{Phenotypic validation of hybrid status}

The major phenotypic criterion that distinguished the F1 hybrids from commercial D. labrax offspring was pigmentation. At larval stages, F1 hybrids could be distinguished from D. labrax by their intense pigmentation (more spots in number and intensity) (Fig. 1a). Later, at the juvenile stage, the spots were easily observed in the hybrids but were lacking in the D. labrax commercial strain (Fig. 1b).

\subsection{Assessment of fertilisation success}

Fertilisation success was higher in all experimental designs when using $D$. punctatus sires than when using D. labrax sires in the intraspecific crosses.

In experiment 1 (Fig. 2a), which used individual West Mediterranean D. labrax dams with good egg quality, fertilisation success rates were significantly higher in interspecific crosses (min-max values from 60-100\%) than in the intraspecific counterpart (min-max values from 7-47\%). Indeed, $p$ values for $\mathrm{F}_{\mathrm{WM}-1}, \mathrm{~F}_{\mathrm{WM}-2}$, and $\mathrm{F}_{\mathrm{WM}-3}$ dams were $10^{-7}, 7 \times 10^{-8}$ and $10^{-6}$, respectively. On average, fertilisation rates in the interspecific crosses were 2.7 fold higher than in the intraspecific one $(80 \%$ vs. $29 \%$ ).

In experiment 3 (Fig. 3a), which also used good quality eggs pooled from Atlantic D. labrax dams, fertilisation rates were also significantly higher in interspecific crosses (min-max values from 61 to $77 \%$ ) than in the intraspecific one (min-max value from 10 to $22 \%)\left(p=4 \times 10^{-23}\right)$. On average, fertilisation rates 

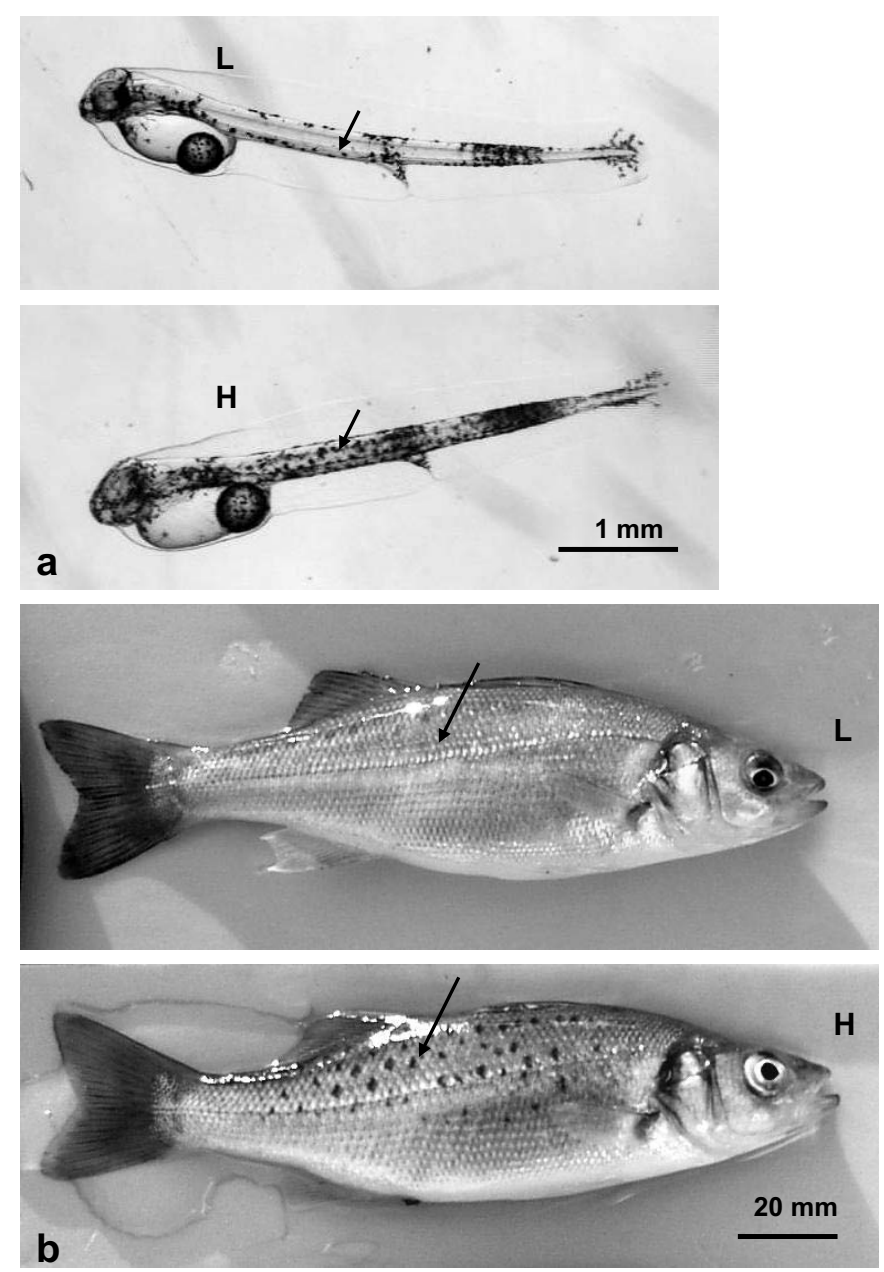

Fig. 1. External appearance of the common sea bass D. labrax (L) and F1 interspecific hybrid D. labrax $\times D$. puntatus $(\mathrm{H})$ at: larval stage, 2 days post-hatching (a), and juvenile stage, 250 days post-hatching (b). As shown by the arrows, the interspecific hybrids were spotted and phenotypically distinct from the farmed $D$. labrax.

in the interspecific crosses were 4.8 fold higher than the intraspecific ones ( $68 \%$ vs. $14 \%)$.

In experiment 2 (Fig. 4a), which used West Mediterranean D. labrax dams with poor egg quality, fertilisation rates were significantly different for $\mathrm{F}_{\mathrm{WM}-4}$ and $\mathrm{F}_{\mathrm{WM}-5}$ dams, with $p$ values of $2 \times 10^{-4}$ and 0.011 , respectively. For dam $\mathrm{F}_{\mathrm{WM}-4}$, interspecific crosses led to a 1.9-fold higher fertilisation rate than the intraspecific counterparts ( $72 \%$ vs. $37 \%)$, with min-max values ranging from $65-80 \%$ vs. $26-43 \%$ (intraspecific crosses). For dam $\mathrm{F}_{\mathrm{WM}-5}$, interspecific crosses led to fertilisation rates $30 \%$ higher than the intraspecific counterparts.

Regarding the intraspecific D. labrax crosses used as the control in the good egg quality experiment (experiment 1), the fertilisation rate in inter-population crosses between West Mediterranean dams and Atlantic sires ( 3 crosses) was double that of the intra-Atlantic population crosses (experiment 3 ): $30 \%$ vs. $15 \%$. For experiment 2 (poor egg quality), average fertilisation a
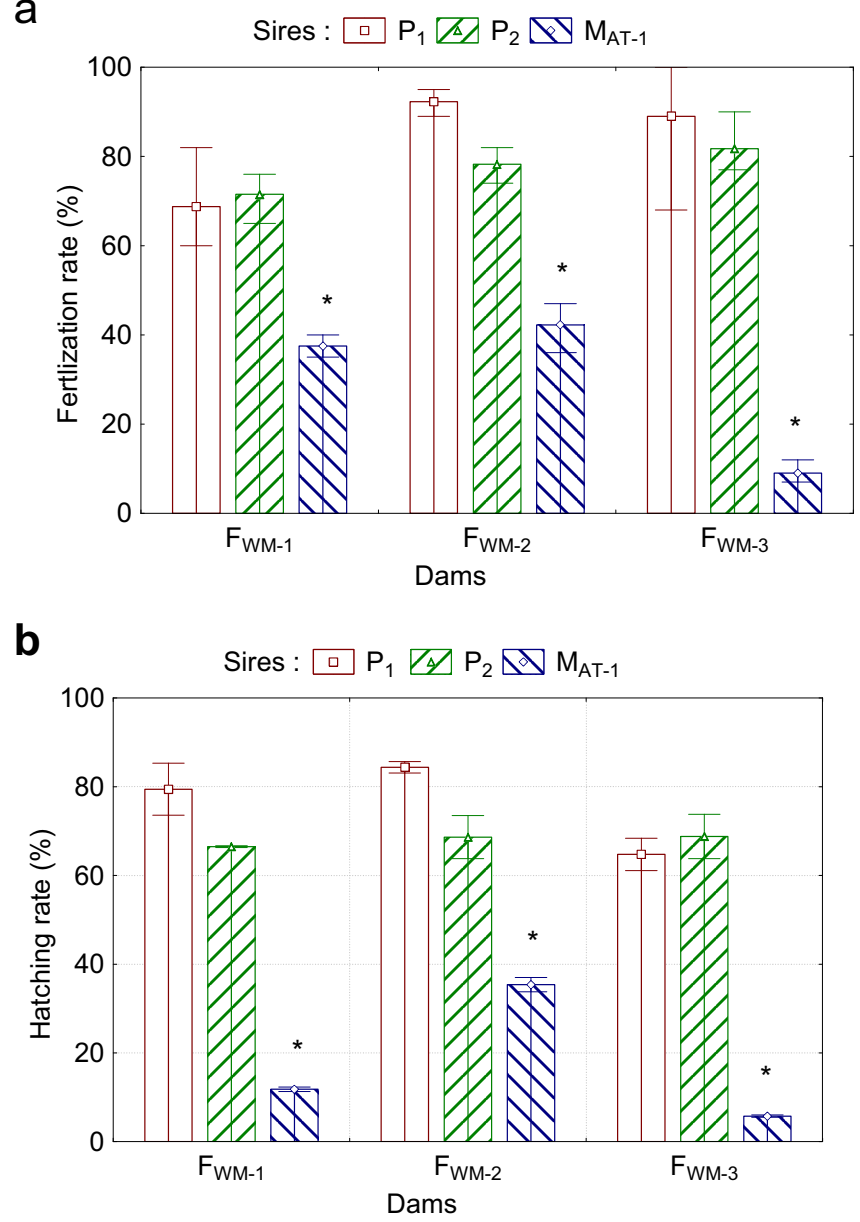

Fig. 2. Histograms showing median, minimum and maximum values of the fertilization rate (a) and hatching rate (b) in experiment 1 : a complete factorial breeding scheme $3 \times 3$ (dams $\mathrm{F}_{\mathrm{WM}-1}, \mathrm{~F}_{\mathrm{WM}-2}$, and $\mathrm{F}_{\mathrm{WM}-3}$, whose eggs were of good quality, individually mated with sires $\mathrm{P}_{1}, \mathrm{P}_{2}$, and $\mathrm{M}_{\mathrm{AT}-1}$ ). The data points significantly different at $p<0.05$ are indicated with an asterisk $(*)$.

rate was $34 \%$ in inter-population crosses and, therefore, approximately equivalent to the value found in experiment 1 .

\subsection{Assessment of hatching rate}

Hatching rate was significantly higher in experiments 1 and 3 , where good quality eggs were used than in experiment 2 where egg quality was poor. In experiment 1 (Fig. 2b), $p$ values for $\mathrm{F}_{\mathrm{WM}-1}, \mathrm{~F}_{\mathrm{WM}-2}$, and $\mathrm{F}_{\mathrm{WM}-3}$ dams were $2 \times 10^{-3}, 3 \times 10^{-3}$ and $2 \times 10^{-3}$, respectively. In experiment 3 (Fig. $3 \mathrm{~b}$ ), $p$ value was $2 \times 10^{-12}$ for the pooled females. On average, hatching rate was 4.0 and 4.6 fold higher using D. punctatus as sires than D. labrax in experiment 1 (Fig. 2b) and 3 (Fig. 3b) respectively.

In experiment 2 (poor egg quality), hatching rate was only significantly different with the $\mathrm{F}_{\mathrm{WM}-5}$ dam $\left(p=6 \times 10^{-5}\right)$, but not with the $\mathrm{F}_{\mathrm{WM}-4}$ dam $(p=0.061)$ (Fig. 4b). 
a

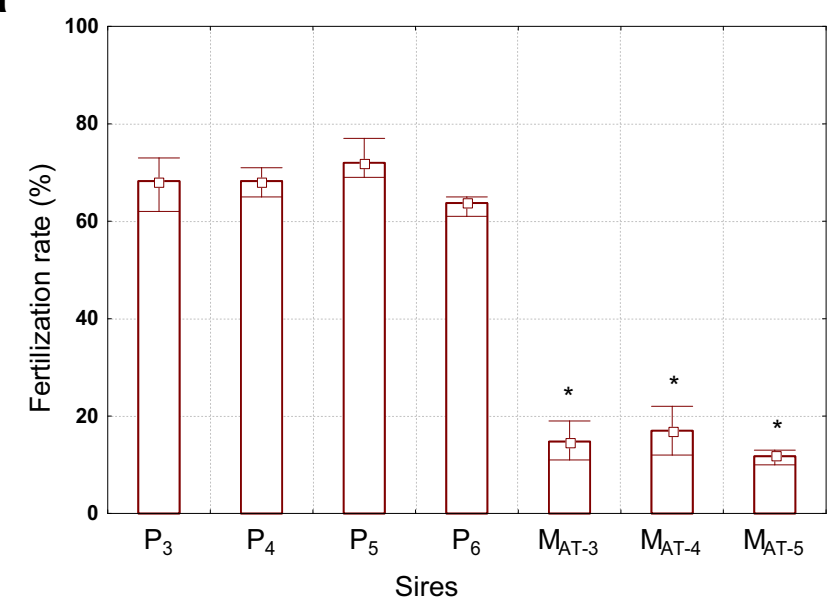

b

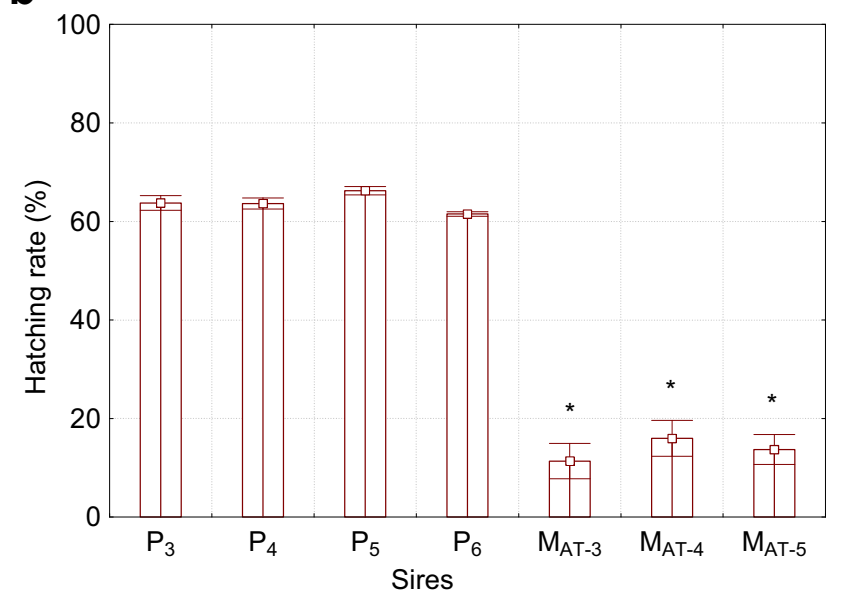

Fig. 3. Histograms showing median, minimum and maximum values of the fertilisation rate (a) and hatching rate (b) in experiment 3 : crossbreeding using pooled eggs from three $D$. labrax dams $\mathrm{F}_{\text {AT-1 }}, \mathrm{F}_{\text {AT-2 }}$, and $\mathrm{F}_{\mathrm{AT}-3}$ with four D. punctatus sires $\mathrm{P}_{3}, \mathrm{P}_{4}, \mathrm{P}_{5}$ and $\mathrm{P}_{6}$ and three D. labrax sires $\mathrm{M}_{\mathrm{AT}-3} ; \mathrm{M}_{\mathrm{AT}-4}$ and $\mathrm{M}_{\mathrm{AT}-5}$. The data points significantly different at $p<0.05$ are indicated with an asterisk $(*)$.

\section{Discussion}

\subsection{Fitness and parental species effects}

The strong repeatability between our breeding experiments shows that interspecific crosses could be performed using D. labrax dams and D. punctatus sires, to produce viable diploid F1 hybrid progenies. The viability of such hybrids was also confirmed by Merlo et al. (2010), who analysed three multigene families as tools for the characterisation of Dicentrarchus hybrids. Our results clearly show that traits such as fertilisation and hatching rate were better in the interspecific cross between D. labrax $\times$ D. punctatus than in the intraspecific D. labrax cross for both an equivalent and limiting sperm concentration on eggs from the same female or pool. Such superior performance of hybrids in traits affecting fecundity would be expected to a
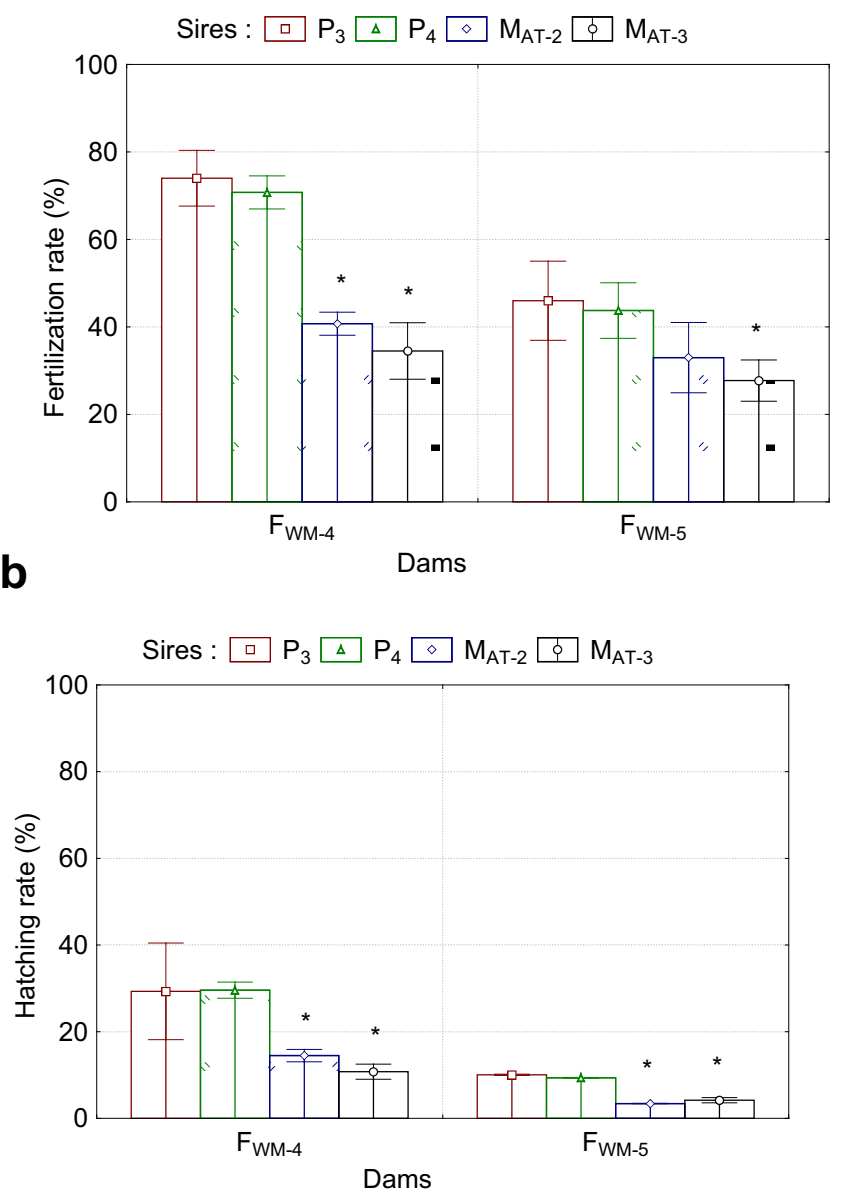

Fig. 4. Histograms showing median, minimum and maximum values of the fertilization rate (a) and hatching rate (b) in experiment 2: a complete breeding factorial scheme $2 \times 4$ (dams $\mathrm{F}_{\mathrm{WM}-4}$ and $\mathrm{F}_{\mathrm{WM}-5}$, whose eggs were of poor quality, mated with sires $\mathrm{P}_{3}, \mathrm{P}_{4}$, and $\mathrm{M}_{\mathrm{AT}-2}, \mathrm{M}_{\mathrm{AT}-3}$ ). The data points significantly different at $p<0.05$ are indicated with an asterisk $(*)$.

enhance fitness. Additionally, the advantage of F1 hybrids over D. labrax parental species at early developmental stages provides evidence of better early-life stage fitness in hybrids. This is not necessarily the case in other species of aquaculture interest. For example, interspecific hybridisation of shrimp had been successfully obtained for Penaeus setiferus $\times$ Penaeus schmitti (Bray et al. 1990) and reciprocal crosses of Penaeus monodon and Penaeus penicillatus (Lin et al. 1998), but spawning rate, hatching rate, and the survival of hybrid progeny to post-larval stages were low compared with intra-specific matings. This fitness reduction was attributed to the genetic mechanisms of outbreeding depression and/or underdominance (Miller et al. 2004).

It is commonly thought that a longer history of genetic isolation leads to a greater accumulation of genomic incompatibilities, related to genetic distance. Viability of hybrids 
decreases with large genetic distances, such as those between genera. In this study, both Dicentrarchus species are closely related, they have a highly sympatric distribution, and they are not physically isolated in the wild (Bonhomme et al. 2002). It is interesting to consider whether the better fertilisation and hatching rates in the interspecific crosses, compared with their intraspecific counterparts can be explained from an evolutionary point of view. One response could be the influence of maternal and paternal effects, which largely govern these early life traits. Such effects have been found to affect early life history survival in salmonids (Nagler et al. 2000; Perry et al. 2005) and in sea bass (Saillant et al. 2001), and are well known to influence embryo development in general (Heath and Blouw 1998). Maternal and paternal effects could differ between the two Dicentrarchus species with regard to their physiological adaptation (temperature and oxygen) and tolerance of captive rearing conditions. Maternal effects, such as egg size and quality, may affect hatch timing and embryonic growth rate and consequently hatching success. These components have been estimated in salmonids (Wang et al. 2007), including whitefish (Rogers and Bernatchez 2006). In our experiments, interspecific and intraspecific crosses were made using the egg from the same female of pool of females (fixed maternal effect), meaning that the observed fitness differences can be linked to the sires. Paternal effect, i.e. spermatozoid quality and viability (beyond solely concentration and motility), may affect mortality or the ability of embryos to cope with the artificial environment. We know that $D$. punctatus has a more southerly geographic distribution and is frequently observed off the Senegal coast while, in contrast to D. labrax, it is never fished in Norway. Moreover, peak spawning of these two species occurs at different times in the nature and so gamete quality may be different between them at any given point in time. In our experiments, no bias due to differential gamete quality of $D$. punctatus and $D$. labrax affected the results. Indeed, these two species had been reared in our facilities, in the same environment (photoperiod, temperature, feeding), for two complete years before experimentation. Thus, synchronism in their spermiation periods had been achieved.

Increased fitness at an early life stage was also recorded in the intraspecific D. labrax crosses, with better performances in inter-population crosses between West Mediterranean dams and Atlantic sires (experiment 1), compared with the intra-Atlantic population crosses (experiment 3). This suggests that West Mediterranean and Atlantic dams are not similar and should be treated differently. However, this higher performance in the progeny of inter-population crosses is not as great as that found in interspecific crosses.

\subsection{Potential impact for sea bass research programs and aquaculture}

The possibility of producing F1 hybrids might provide a new direction for sea bass genetic research efforts. Fish are widely used in numerous fields of basic and applied research. Fish currently represent the third most common laboratory vertebrate group in terms of number of species studied, and are growing in importance. Although considerable progress has been made with regards to reproductive traits of Dicentrarchus, more research is required to provide a better understanding of its reproductive biology. It will be especially important to develop the means to predict and ensure the complete maturation of individual females chosen for spawning on the basis of their genetic value as broodstock. In our experience, for a given group of candidate sea bass spawners, only about a half of the females can be successfully reproduced using the best procedure available. The remainder fail to complete egg growth or yield eggs of low quality. Interspecific hybrid could facilitate mapping of large numbers of QTL (quantitative trait loci) of interest to the sea bass linkage map due to the great difference between the parental species for many phenotypic traits (Ky et al. 2000). This could possibly be achieved through an interspecific sea bass linkage map.

The genetic mechanism underlying the increased fitness at early life stages could be linked to heterosis. This could be examined in future studies by producing pure spotted sea bass families also. Other hybrid genetic combinations could be explored to test fitness or outbreeding depression though the study of F1 reciprocal crosses (D. punctatus dams and D. labrax sires), F2 hybrids and G2 (second generation) backcrosses. The potential sterility of some F1 progeny could be used to prevent accidental escape and gene impact on natural populations.

From a practical standpoint, commercial production of interspecific F1 hybrids between D. labrax and D. punctatus could represent a new potential for the farming industry if fitness advantages were also found for the main aquaculture traits of interest, including growth performance, hardiness and disease resistance. Production of new improved synthetic breeds with cytogenetic (ploidy level) manipulation of these F1 hybrids could be explored. In the future, this could lead to the maintenance of a new fish broodstock in commercial hatcheries or a long term cryopreservation unit for D. punctatus semen. In Morone, the sister genus of Dicentrarchus, interspecific striped bass hybrids (Morone chrysops $\times$ M. saxatilis) have been found to offer considerable potential, with regards to growth, hardiness and disease resistance (Kerby and Harrell 1990; Harrell 1997), for aquaculture throughout the United States (Hanfman 1993), as well as in other countries such as Israel and Taiwan (Garber and Sullivan 2006).

Acknowledgements. We wish to thank Mrs Helen Boudry and Mrs. Shital Gaucher Swarup for editing the English of this manuscript.

\section{References}

Aegerter S., Jalabert B., Bobe J., 2005, Large scale real-time PCR analysis of mRNA abundance in rainbow trout eggs in relationship with egg quality and post-ovulatory ageing. Mol. Reprod. Dev. 72, 377-385.

Allegrucci G., Fortunato C., Sbordoni V., 1997, Genetic structure and allozyme variation of sea bass (Dicentrarchus labrax and D. punctatus) in the Mediterranean Sea. Mar. Biol. 128, 347-358. 
Allegrucci G., Caccone A., Sbordoni V., 1999, Cytochrome $b$ sequence divergence in the European sea bass (Dicentrarchus labrax) and phylogenetic relationships among some Perciformes species. J. Zool. Systemat. Evol. Res. 37, 149-156.

Bartley D.M., Rana K., Immink A.J., 2001, The use of inter-specific hybrids in aquaculture and fisheries. Rev. Fish Biol. Fish. 10, 325-337.

Bobe J., Labbé C., 2010, Egg and sperm quality in fish. Gen. Comp. Endocrinol. 165, 535-548

Bonhomme F., Naciri F., Bahri-Sfar L., Lemaire C., 2002, Comparative analysis of genetic structure of two species of marine fish Dicentrarchus labrax and Dicentrarchus punctatus. C. R. Biol. 325, 213-220.

Bonnet E., Fostier A., Bobe J., 2007a, Microarray-based analysis of fish egg quality after natural or controlled ovulation. BMC Genomics. 8, 1-17.

Bonnet E., Montfort J., Esquerre D., Hugot K., Fostier A., Bobe J., $2007 \mathrm{~b}$, Effect of photoperiod manipulation on rainbow trout (Oncorhynchus mykiss) egg quality: A genomic study. Aquaculture 268, 13-22.

Bray W.A., Lawrence A.L., Lester L.J., Smith L.L., 1990, Hybridisation of Penaeus setiferus (Linnaeus 1767) and Penaeus schmitti Burkenroad, 1936 (Decapoda). J. Crust. Biol. 10, 278-283.

Bromage N., Jones J., Randall C., Thrush M., Davies B., Springate J.R.C., Duston J., Barker G., 1992, Broodstock management, fecundity, egg quality and the timing of egg production in the rainbow trout (Oncorhynchus mykiss). Aquaculture 100, 141166.

Bromage N., Bruce M., Basavaraja N., Rana K., Shields R., Young C., Dye J., Smith P., Gillespie M., Gamble J., 1994, Egg quality determinants in finfish: the role of overripening with special reference to the timing of stripping in the Atlantic halibut Hippoglossus hippoglossus. J. World Aquac. Soc. 25, 13-21.

Bromage N.R., 1995, Broodstock management and seed qualitygeneral considerations. In: Bromage N.R., Roberts R.J. (Eds.), Broodstock Management and Egg and Larval Quality. Blackwell Science, Oxford, pp. 1-24.

Brooks S., Tyler C.R., Sumpter J.P., 1997, Egg quality in fish: what makes a good eggs? Reviews in Fish Biology and fisheries 7, $387-416$.

Caccone A., Allegrucci G., Fortunato C., Sbordoni V., 1997, Genetic differenciation within the european sea bass (D. labrax) as revealed by RAPD-PCR assays. J. Hered. 88, 316-324.

Campbell N.A., 1990, Biology, 2nd edn. Benjamin/Cummings Publishing Company, Redwood City, Calif.

Campbell P.M., Pottinger T.G., Sumpter J.P., 1992, Stress reduces the quality of gametes produced by rainbow trout. Biol. Reprod. 47, $1140-1150$.

Congiu L., Dupanloup I., Patarnello T., Fontana F., Rossi R., Arlati G., Zane L., 2001, Identification of interspecific hybrids by amplified fragment length polymorphism: the case of sturgeon. Mol. Ecol. 10, 2355-2359.

Crespel A., Rime H., Fraboulet E., Bobe J., Fauvel C., 2008, Egg quality in domesticated and wild seabass (Dicentrarchus labrax): a proteomic analysis. Cybium 32, 205.

Christiansen R., Torrisen O.J., 1997, Effects of dietary astaxanthin supplementation on fertilisation and egg survival in Atlantic salmon (Salmo salar). Aquaculture 153, 51-62.
Desvignes T., Fauvel C., Bobe J., 2011, The nme gene family in zebrafish oogenesis and early development. NaunynSchmiedebergs Arch. Pharmacol. 384, 439-449.

Fairfull R.W., Gowe R.S., Nagai J., 1987, Dominance and epistasis in heterosis of White Leghorn strain crosses. Can. J. Anim. Sci. $33,663-80$.

Fauvel C., Omnes M.H., Suquet M., Normant Y., 1992, Enhancement of the production of turbot, Scophthalmus maximus (L.) larvae by controlling overripening in mature females. Aquac. Fish. Manage. 23, 209-216

Fauvel C., Suquet M., Dreanno C., Zonno V., Menu B., 1998, Cryopreservation of seabass (Dicentrarchus labrax) spermatozoa in experimental and production simulating conditions. Aquat. Living Resour. 11, 387-394.

Fauvel C., Bon E., Le Menn F., 1999, Post vitellogenic modifications of sea bass oocytes in captive population. Morphological and functional description. In: Stefansson S.O. (Ed.), Proc. 6th Int. Symp. Reproductive Physiology of Fish Department of Fisheries and Marine Biology University of Bergen.

Fauvel C., Suquet M., 1999, La qualité des gamètes chez le bar et quelques déterminants en aquaculture. Piscic. Fr. 134, 5-10.

Flock D.K., Ameli H., Glodek P., 1991, Inbreeding and heterosis effects on quantitative traits in a White Leghorn population under long-term reciprocal recurrent selection. British Poultry Sci. 33, $451-462$.

Fornies M.A., Mañanos E., Carrillo M., Laureau S., Mylonas C.C., Zohar Y., Zanuy S., 2001, Effectiveness of different GnRHa-delivery systems on spawning induction in sea bass (Dicentrarchus labrax). Aquaculture 202, 221-234.

Garber A.F., Sullivan C.V., 2006, Selective breeding for the hybrid striped bass (Morone chrysops Rafinesque $\times$ M. saxatilis Walbaum) industry: status and perspectives. Aquac. Res. 37, 319338.

Garcia De Leon F.J., Dallas J.F., Chatain B., Canonne M., Versini J.J., Bonhomme F., 1995, Development and use of microsatellite markers in seabass, Dicentrarchus labrax (Linnaeus 1758) (Perciforms: Serranidae). Mol. Mar. Biol. Biotechnol. 4, 62-8.

Garcia De Leon F.J., Chikhi L., Bonhomme F., 1997, Microsatellite polymorphism and population subdivision in natural populations of European sea bass Dicentrarchus labrax (Linnaeus 1758). Mol. Ecol. 6, 51-62.

Hanfman D.T., 1993, The status and potential of aquaculture in the united states: an overview and bibliography. United States Department of Agriculture, National Agricultural Library Beltsville, MD.

Harrell R.M., 1997, Hybridization and genetics. In: Harell R.M. (Ed.), Striped bass and other Morone culture, pp. 217-234.

Heath D.D., Blouw D.M., 1998, Are maternal effects in fish adaptative or merely physiological side effects? In: Mousseau T.A., Fox C.W. (Eds.), Maternal effects as adaptations. Oxford University Press, New York, pp. 178-201.

Hulata G., 1995, A review of genetic improvement of the common carp (Cyprinus carpio L.) and other cyprinids by crossbreeding, hybridization and selection. Aquaculture 129, 143-155.

Kerby J.H., Harrell R.M., 1990, Hybridization, genetic manipulation, and gene pool conservation of striped bass, Chapter 11. In: Harell R.M., Kerby J.H., Minton R.V. (Eds.), Culture and propagation of striped bass and its hybrids, pp. 159-190. 
Kjorsvik E., Mangor-Jensen A., Holmefjord I., 1990, Egg quality in fishes. Adv. Mar. Biol. 26, 71-113.

Kjorsvik E., 1994, Egg quality in wild and broodstock cod Gadus morhua L. J. World Aquac. Soc. 25, 22-29.

Kjorsvik E., Hoehne-Reitan K., Reitan K.I., 2003, Egg and larval quality criteria as predictive measures for juvenile production in turbot (Scophthalmus maximus L.). Aquaculture 227, 9-20.

Ky C.L., Barre P., Lorieux M., Trouslot P., Akaffou S., Louarn J., Charrier A., Hamon S., Noirot M., 2000, Interspecific genetic linkage map, segregation distortion and genetic conversion in coffee (Coffea sp.). Theor. Appl. Genet. 101, 669-676.

Lam T.J., 1994, Hormones and egg/larval quality in fish. J. World Aquac. Soc. 25, 2-12.

Lemaire C., Versini J.J., Bonhomme F., 2005, Maintenance of genetic differentiation across a transition zone in the sea: discordance between nuclear and cytoplasmic markers. J. Evol. Biol. 18, 7080.

Lin M.N., Ting Y.Y., Hanyu I., 1998, Hybridization of two closethelycum penaeid species, Penaeus monodon $\times$ Penaeus penicillatus and $P$. penicillatus $\times P$. monodon, by means of spermatophore transplantation. Bull. Taiwan Fish. Res. Inst. 45, 83-101.

Lynch M., Walsh B., 1998, Genetics and analysis of quantitative traits. Sinauer Associates Inc. Sunderland, MA.

Mayer I., Shakley S.E., Witthames P.R., 1990, Aspects of the reproductive biology of the bass, Dicentrarchus labrax L. II: Fecundity and pattern of oocyte development. J. Fish Biol. 36, 141148.

Medeiros A.P.T., Chellappa S., Yamamoto M.E., 2007, Agonistic and reproductive behaviour in males of red hybrid tilapia, Oreochromis niloticus (Linnaeus) $\times O$. mossambicus (Peters) (Osteichthyes, Cichlidae). Braz. J. Biol. 67, 701-706.

Merlo M.A., Cross I., Chairi H., Manchando M., Rebordinos L., 2010, Analysis of three bmultigene families as useful tools in species characterization of two closely-species, Dicentrarchus labrax, Dicentrarchus punctatus and their hybrids. Genes Genet. Syst. 85, 341-349.

Miller L.M., Close T., Kapuscinski A.R., 2004, Lower fitness of hatchery and hybrid rainbow trout compared to naturalised populations in Lake Superior tributaries. Mol. Ecol. 13, 3379-3388.
Nagahama Y., 1995, Teleost oocyte maturation - actuality and potentiality. Aquaculture 135, 75-76.

Nagler J.J., Parsons J., Cloud J.G., 2000, Single pair mating indicates maternal effects on embryo survival in rainbow trout, Oncorhynchus mykiss. Aquaculture, 184, 177-183.

Noga E.J., Kerby J.H., King W., Aucoin D.P., Giesbrecht F., 1994, Quantitative comparison of the stress response of striped bass (Morone saxatilis) and hybrid striped bass (Morone saxatilis $\times$ Morone chrysops and Morone saxatilis $\times$ Morone americana). Am. J. Vet. Res. 55, 405-409.

Perry G.M.L., Audet C., Bernatchez L., 2005, Maternal genetic effects on adaptive divergence between anadromous and resident brook charr during early life history. J. Evol. Biol. 18, 13481361.

Rogers S.M., Bernatchez L., 2006, The genetic basis of intrinsic and extrinsic post-zygotic reproductive isolation jointly promoting speciation in the lake whitefish species complex (Coregonus clupeaformis). J. Evol. Biol. 19, 1979-1994.

Saillant E., Chatain B., Fostier A., Przybyla C., Fauvel C., 2001, Parental influence on early development in the European sea bass J. Fish Biol. 58, 1585-1600.

Suquet M., Omnes M.H., Normant Y., Fauvel C., 1992, Assessment of sperm concentration and motility in turbot (Scophthalmus maximus). Aquaculture 101, 177-185.

Vitturi R., Mazzola A., Catalano E., Lo Conte M.R., 1990, Karyotype analysis, nuclear regions (NORs), and C-banding pattern of Dicentrarchus labrax (L.) and Dicentrarchus punctatus (Blok 1792) (Pisces, Perciformes) with evidence of chromosomal structural polymorphism. Cytologia 55, 425-430.

Wallace R., Selman K., 1981, Cellular and dynamic aspects of oocyte growth in teleosts. Am. Zool. 21, 325-343.

Wang I.A., Gilk S.E., Smoker W.W., Gharrett A., 2007, Outbreeding effect on embryo development in hybrids of allopatric pink salmon (Oncorhynchus gorbuscha) populations, a potential consequence of stock translocation. Aquaculture 272, 152-160.

Watanabe T., Kiron V., 1995, Red sea bream (Pagrus major). Broodstock management and egg and larval quality. In: Bromage N.R., Roberts R.J. (Eds.), Blackwell Science, Oxford, pp. 398413. 